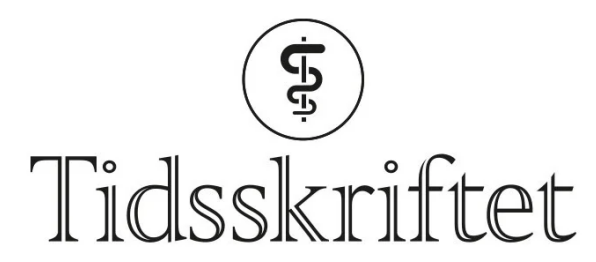

DEN NORSKE LEGEFORENING

\title{
Manglende kvalitetssikring av kostholdsrådene
}

DEBATT

\section{HANNE STORHAUG JENSEN}

hanneskjokken@gmail.com

Hanne Storhaug Jensen har en bachelorgrad i ernæring fra Bjørknes Høyskole og er tidligere medisinstudent ved Universitetet i Oslo. Hun har skrevet prosjektoppgave på medisinstudiet og bacheloroppgave i ernæring om fett og kostråd. Hun driver også Spirene på Nesodden. Forfatter har fylt ut ICMJE-skjemaet og oppgir ingen interessekonflikter.

\section{INGE ANDREAS LINDSETH}

Inge Andreas Lindseth er klinisk ernæringsfysiolog og jobber ved Balderklinikken samt i Økologisk Norge.

Forfatter har fylt ut ICMJE-skjemaet og oppgir ingen interessekonflikter.

\section{Det vitenskapelige grunnlaget for Helsedirektoratets kostråd blir utarbeidet av Nasjonalt råd for ernæring. Vi etterlyser strengere krav til rapporter som begrunner kostholdsrådene.}

Alle mennesker - også våre fremste eksperter - kan tendere mot å vekte informasjon skjevt. De nyeste norske kostrådene ble gitt ut i 2011 (1). Vi blir anbefalt å velge magert kjøtt, magre meieriprodukter og bytte ut smør med myk margarin og planteoljer. Kostrådene gir inntrykk av at å bytte ut mettet med flerumettet fett har en sterk effekt på hjerte- og karsykdommer. En kunnskapsoppsummering fra FNs organisasjon for ernæring og landbruk (FAO) (2 ) er Helsedirektoratets hovedkilde for vurderingen av helseeffekter av fettsyrer (3). Men selv om det konkluderes med sterke effekter $(\underline{1}, \underline{2})$, var funnene fra analysene det refereres til $(4,5)$ langt fra entydige. I metaanalyser av prospektive kohortstudier ble det blant annet funnet redusert risiko for koronar hjertesykdom og død ved å erstatte mettet fett med flerumettet fett (4.), ingen sammenheng mellom inntak av mettet fett og hjerte- og karsykdommer eller død (5), økt risiko for koronar hjertesykdom ved å erstatte mettet fett med karbohydrater (4.) og sterk signifikant sammenheng mellom høyere inntak av flerumettet fett og koronar dødelighet (5). 
«Det er umulig for leseren - uavhengig av faglig kompetanse - å vurdere

hvorfor de oppgitte konklusjonene ble trukket»

De motstridende resultatene om fett er oppgitt i kostrapporten fra 2011 ((1) , s. 333), men funnene som taler mot kostrådene er ikke diskutert. Det er heller ikke oppgitt hvordan de ulike resultatene er vektet.

\section{Uklart hvordan studiene velges og vektes}

Helsedirektoratet bestilte en ny vurdering av kunnskapsgrunnlaget om fett, og denne ble publisert i 2017 ( $\underline{6}$ ). Arbeidsgruppen fra ernæringsrådet konkluderer her med at de norske rådene om fett fra 2011 ikke er svekket. Rapporten har referert til en stor mengde litteratur, men det er ikke beskrevet hvordan resultatene er vektet. Det er umulig for leseren uavhengig av faglig kompetanse - å vurdere hvorfor de oppgitte konklusjonene ble trukket.

Noen studier og metaanalyser er også utelatt, uten at det kommer frem hvorfor.

Eksempelvis ble en metaanalyse fra 2010 inkludert (7.), selv om det eksisterte to oppdaterte utgaver av denne $(\underline{8}, 9$. .). De oppdaterte versjonene hadde med nye data fra to av de kliniske studiene, nemlig Sydney Diet Heart Study og Minnesota Coronary Experiment. I Sydney Diet Heart Study hadde gruppen som spiste mer flerumettet fett $ø$ kt risiko for å d $\varnothing$ av alle årsaker, samt for å få kardiovaskulær sykdom og koronar hjertesykdom. Dette på tross av at serumkolesterolet var lavere i gruppen som spiste mer flerumettet fett ( $\underline{8})$. I Minnesota Coronary Experiment fikk deltakerne i intervensjonsgruppen - de som spiste mer flerumettet fett - som forventet senket kolesterolet, men uten gunstige effekter på sykdom og død (9.). Vi stiller spørsmål ved at de oppdaterte tallene fra Sydney og Minnesota, som står i tydelig kontrast til dagens kostråd, ikke er diskutert i rapporten fra 2017. I et vedlegg

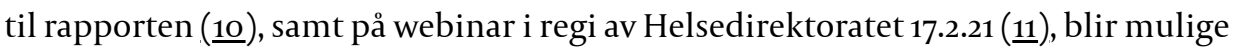
feilkilder i disse studiene trukket fram, og man kan få inntrykk av at dette er grunnen til at man bør se bort fra resultatene. Likevel brukes andre kliniske studier med minst like store

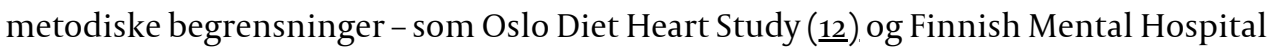
Study $(\underline{13}, 14$. $)$ - for å støtte opp om kostrådene $(\underline{1}, 3, \underline{6}, 15)$, uten at svakhetene trekkes fram i særlig grad.

\section{Først og fremst ikke skade}

Rådene om fett ble opprinnelig gitt grunnet en antatt kobling mellom mettet fett og hjertesykdom. I den nyeste ekspertuttalelsen ( $\underline{16})$ er ordlyden endret, og det står at mettet fett ikke er farlig i seg selv. Rådene er derimot fortsatt de samme, angivelig fordi det likevel skal være gunstig å bytte ut mettet fett med flerumettet fett. Men når all tilgjengelig litteratur inkluderes, mangler støtten for anbefalinger om å øke inntaket av flerumettet fett fra oljer og margariner og redusere inntaket av mettet fett fra kjøtt, smør og andre meieriprodukter.

«Det er umulig for leseren - uavhengig av faglig kompetanse - å vurdere hvorfor de oppgitte konklusjonene ble trukket»

Kostråd har stor betydning i samfunnet, og det bør derfor stilles strengere krav til rapporter som begrunner rådene. Motstridende funn må diskuteres med lik vekting, og usikkerhet må komme tydelig frem. De ferdige rapportene bør vurderes eksternt av fagfeller før 
publikasjon for å sikre at konklusjonene stemmer med funnene, og at evidensen er sterk nok til å gi kostråd. Ved fravær av sterk, entydig evidens må det også være et alternativ å la være å gi råd som i det lange løp kan ha utilsiktede effekter på folks helse.

\section{LITTERATUR}

1. Kostråd for å fremme folkehelsen og forebygge kroniske sykdommer. Metodologi og vitenskapelig kunnskapsgrunnlag. Oslo: Nasjonalt råd for ernæring, 2011.

https://www.helsedirektoratet.no/rapporter/kostrad-for-a-fremme-folkehelsen-og-forebygge-

kroniske-sykdommer-metodologi-og-vitenskapelig-

kunnskapsgrunnlag/Kostr\%C3\%A5d\%2ofor\%20\%C3\%A5\%2ofremme\%2ofolkehelsen\%2oog\%2oforebygge \%2okroniske\%2osykdommer\%20\%E2\%80\%93\%2ometodologi\%20og\%2ovitenskapelig\%2okunnskapsgru nnlag.pdf/_/attachment/inline/2a6293eo-169e-41bd-a872-

f3952dbb22c2:odog926111d614e6059e8o4b7f9b21c17bdoc1cd/Kostr\%C3\%A5d\%2ofor\%20\%C3\%A5\%2ofrem me\%2ofolkehelsen\%2oog\%2oforebygge\%2okroniske\%2osykdommer\%20\%E2\%80\%93\%2ometodologi\%2o og\%20vitenskapelig\%2okunnskapsgrunnlag.pdf Lest 15.4.2021.

2. Fats and fatty acids in human nutrition. Report of an expert consultation. FAO food and nutrition paper 91. Roma: Food and agriculture organization of the United Nations, 2010.

https://www.who.int/nutrition/publications/nutrientrequirements/fatsandfattyacids_humannutriti on/en/ Lest 15.4.2021.

3. Blomhoff R. Feil om fett. Tidsskr Nor Legeforen 2013. https://tidsskriftet.no/2013/o2/kommentar/feilom-fett Lest 15.4.2021.

4. Jakobsen MU, O'Reilly EJ, Heitmann BL et al. Major types of dietary fat and risk of coronary heart disease: a pooled analysis of 11 cohort studies. Am J Clin Nutr 2009; 89:1425-32. [PubMed][CrossRef]

5. Skeaff CM, Miller J. Dietary fat and coronary heart disease: summary of evidence from prospective cohort and randomised controlled trials. Ann Nutr Metab 2009; 55: 173-201. [PubMed][CrossRef]

6. Kostråd om fett - En oppdatering og vurdering av kunnskapsgrunnlaget. Oslo: Nasjonalt råd for ernæring, 2017.https://www.helsedirektoratet.no/rapporter/kostrad-om-fett-en-oppdatering-ogvurdering-av-

kunnskapsgrunnlaget/Kostr\%C3\%A5d\%20om\%2ofett\%20\%E2\%80\%93\%2oEn\%2ooppdatering\%20og\%2ovu rdering\%2oav\%2okunnskapsgrunnlaget.pdf/_/attachment/inline/6dc3e4d8-3336-45e3-9o88-

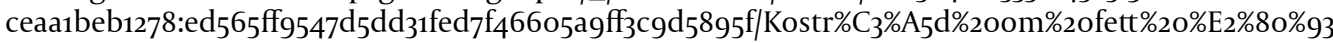
\%20En\%2ooppdatering\%20og\%2ovurdering\%20av\%2okunnskapsgrunnlaget.pdf Lest 15.4.2021.

7. Ramsden CE, Hibbeln JR, Majchrzak SF et al. n-6 fatty acid-specific and mixed polyunsaturate dietary interventions have different effects on CHD risk: a meta-analysis of randomised controlled trials. Br J Nutr 2010; 104: 1586-6oo. [PubMed][CrossRef]

8. Ramsden CE, Zamora D, Leelarthaepin B et al. Use of dietary linoleic acid for secondary prevention of coronary heart disease and death: evaluation of recovered data from the Sydney Diet Heart Study and updated meta-analysis. BMJ 2013; 346: e8707. [PubMed][CrossRef]

9. Ramsden CE, Zamora D, Majchrzak-Hong S et al. Re-evaluation of the traditional diet-heart hypothesis: analysis of recovered data from Minnesota Coronary Experiment (1968-73). BMJ 2016; 353: i1246. [PubMed][CrossRef]

10. Arnesen E, Hjelmesæth J, Retterstøl K. Kostråd om fett - En oppdatering og vurdering av kunnskapsgrunnlaget. Vedlegg. Oslo: Nasjonalt råd for ernæring, 2017.

http://www.ernaeringsradet.no/wp-content/uploads/2017/05/Kostr\% $\mathrm{C}_{3} \% \mathrm{~A}_{5} \mathrm{~d}$-fett-oppdatering-ogvurdering-av-kunnskapsgrunnlaget-Vedlegg.pdf?

fbclid=IwAR2n7yfTmPPwVfN2onuJe7T331WzZLovgUkMrXoKivh3Z2kGsZaSQldtKLk Lest 15.4.2021.

11. Nasjonalt råd for ernæring. Lansering av to arbeider fra Nasjonalt råd for ernæring. https://www.helsedirektoratet.no/konferanser/nytt-fra-nasjonalt-rad-for-ernaeringwebinar\#omwebinaret Lest 15.4.2021.

12. Leren P. The effect of plasma-cholesterol-lowering diet in male survivors of myocardial infarction. A controlled clinical trial. Bull N Y Acad Med 1968; 44: 1012-20. [PubMed]

13. Miettinen M, Turpeinen O, Karvonen MJ et al. Dietary prevention of coronary heart disease in women: the Finnish mental hospital study. Int J Epidemiol 1983; 12: 17-25. [PubMed][CrossRef]

14. Turpeinen O, Karvonen MJ, Pekkarinen M et al. Dietary prevention of coronary heart disease: the Finnish Mental Hospital Study. Int J Epidemiol 1979; 8: 99-118. [PubMed][CrossRef]

15. Arnesen E. Ny rapport om mettet fett: Reaksjoner på rapporten.

https://www.ntfe.no/asset/2017/03/Ern\%C3\%A6ring_2017-03_050-052.pdf Lest 15.4.2021. 
16. Ekspertuttalelse om fett. Oslo: Nasjonalt råd for ernæring, 2021. https://www.helsedirektoratet.no/om-oss/organisasjon/rad-og-utvalg/nasjonalt-rad-forernaering/Ekspertuttalelse\%20om\%2ofett,\%20Nasjonalt\%2or\%C3\%A5d\%2ofor\%2oern\%C3\%A6ring,\%2ofe bruar\%202021.pdf/_/attachment/inline/76oob772-d4da-41cb-bbo6-

290304b68b2a:eob8oaf701cd6ad88c21ec61940d6ao57d126d8d/Ekspertuttalelse\%2oom\%2ofett,\%2oNasj onalt\%20r\%C3\%A5d\%2ofor\%20ern\%C3\%A6ring,\%2ofebruar\%202021.pdf Lest 15.4.2021.

Publisert: 14. mai 2021. Tidsskr Nor Legeforen. DOI: 10.4045/tidsskr.21.0214

Mottatt 18.3.2021, første revisjon innsendt 12.4.2021, godkjent 15.4.2021.

(C) Tidsskrift for Den norske legeforening 2023. Lastet ned fra tidsskriftet.no 26. april 2023. 